\title{
原著
}

\section{ニホンザルの新センサス法、ブロック分割定点 調査法の有效性について}

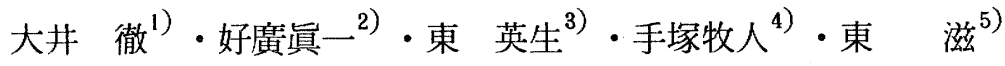 \\ 1）森林総合研究所東北支所 \\ 2) 龍谷大学経営学部 \\ 3) ワイルドライフワークショップ \\ 4）野生動物保護管理事務所 \\ 5）京都大学霊長類研究所
}

\section{はじめに}

昼行性の霊長類の個体数（あるいは集団の数） 推定には，ラインセンサス法が一般に用いられて きた。この方法は，できるだけ長距離の直線のセ ンサスラインの設定と踏査が必要なので, 平坦地 に生息する霊長類の調査に適用されている(Defler \& Pintor, 1985 ; Brockelman \& Ali, 1987など)。 一方, 起伏の多い山岳地帯を生息域とするニホン ザルには，ラインセンサス法は適用されなかった。 ニホンザルのセンサスにおいて，一般にとられ た方法は，林道や登山道などを利用して群れの探 索を行い，報告書，論文には通常記述されること のない調査者の判断で整理された集団の発見情報 から群れ密度を算出するというあのである。結果 の精度についても「ほぼ完全に発見できたである う」などという主観的な記述がされることが多い (例えば, 東他, 1984)。従って, 調査結果の信 頼性は, 調査者の知識や経験に大きく依存し，し かあ熟練した調査者を充分な数だけ集めるのは困 難な場合が多いので，精度の高い調査を広域的に 行うには限界があった。

近年, 保護管理の側面から，群れの分布状態や 個体数を一定の精度で広域的に調查する必要性が ますます高まっている。そこで我々は，サルにつ
いて簡単な知識しか持たない調査経験の浅い人間 であ多人数いれば実施可能なセンサス法（ブロッ ク分割定点調查法）を考案し，試行した。その際， 群れ数が既に判明している地域での適用と, 群れ の直接追跡を併用することにより，乙のセンサス 法の有効性を検討した。

\section{調查地域}

調査は，鹿児島県屋久島西部の国割岳西斜面の， $9.5 \mathrm{~km}^{2}$ (Fig. 1) の地域で行った。標高は0-800 $\mathrm{m}$ であり, 所々基盤岩の露出する急峻な地形でラ インセンサスには不向きな地域である。調查地域 のほとんよ゙がスダジイ (Castanopsis cuspidata), タブノキ (Machilus thunbergii) などの常緑の暖 温帯林で被われ，アコウ(Ficus wightiana), ガ ジュマル (Ficus microcarpa) なよ゙の亜熱帯性植 物屯混在している。標高約 $160 \mathrm{~m}$ の等高線に沿っ ては，県道が走っており，道路沿いは，アカメガ シワ(Mallotus japonicus), ウラジロエノキ(Trema orientalis) などからなる代償植生となっている (Maruhashi，1980；田川，1980）。常緑広葉樹 林が優先するこの地域は一年を通じて林内の見通 しが悪い。

この地域では，林道を横切る群れの個体数調査

1994年 6 月12日受付, 1994年 7 月22日受理 


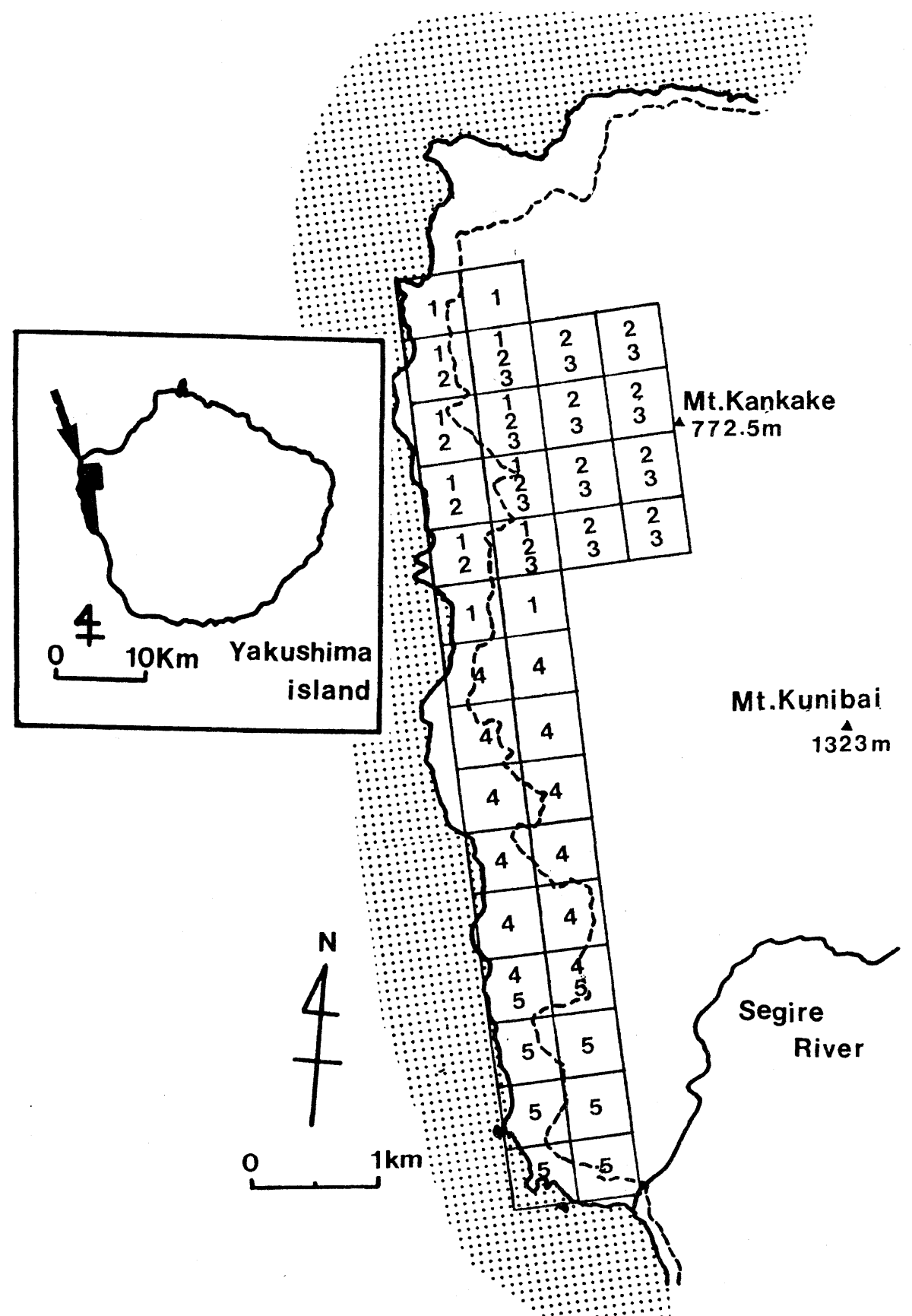

Fig. 1. Location of the research area, and the disposition of the quadrats. The arrow indicates the position of the research area in Yakushima island. An area of each census was given name, and shown in the map as the quadrats numbered the same figure: Hanyama area numbered 1; Hanyama-Kankake (A) area, 2; HanyamaKankake (B) area, 3; Kawahara area, 4; Mankichi area, 5. 
がほぼ毎年行われている。さらに，半山地域 (Fig. 1) では, 1973年以来, 複数の群れについて個体 識別に基づく調査が継続されていたので，本調查 に先立ち群れ数と分布の概要が明らかになってい た。

\section{ブロック分割定点調查法}

地図上で，調査区域を $500 \mathrm{~m}$ 四方の方形区（ブ ロック）に分割する。各々のブロックのほぼ中央 のできるだけ見晴らしのよい一地点を定点と定め 調查者を配置する。各ブロックの調查者は定点か らブロック内の集団を視覚 (双眼鏡使用)，聴覚 の両方を用いて一斉に探索するが，集団発見後は， 集団の動きを定点から追跡し，その軌跡を地図に 記入するとともに，トランシーバで互いに連絡を とることにより，集団の広がりや，他集団との位 置関係を掝む。乙れらの情報により断続的に発見 される集団の関係（同一の群れか別の群れか）を 推測し, 重複カウントを除いた上で群れの分布と 数を推定する。ブロックの大きさは, 調查者の位 置からブロックの境界までの距離が，おおよそ二 ホンザルの叫び声 (Itani, 1965のA-7〜A-12, B，C）か観测者に充分聞こえると経験的に考えら れる200-300 m となるよう決定した。

\section{調查方法}

1990年 8 月 2 日から 8 月 8 日の 7 日間にわたっ て，40名の調查員によってブロック分割定点調查 法の精度と再現性を検討するための調査を行った。 定点に配置された調査者は 1 名を除いてサルの観 察経験がないかほとんどなく，調査に先だって 1 日はサルの観察や探索の仕方についての訓練を行 った。定点の調査者はデータシートに，サルの観 察時間, 発見位置, 最初にサルを発見した手がか り（サルの姿，音声，枝摇れの音，他の定点から の連絡など)，集団を発見したか単独個体を発見 したか, 気象状態 (天候, 風力) なよ゙の項目を記 録した。定点での探索は，07:00-17:00の時 間帯に行った。

調查域全体を 5 つの調查地区 ((1)半山地区, 3 $\mathrm{km}^{2}$; (2) 半山一カンカケ(A)地区, $4 \mathrm{~km}^{2}$; (3) 半
山一カンカケ (B) 地区, $3 \mathrm{~km}^{2}$ ，(4)川原地区， 3 $\mathrm{km}^{2}$ ；(5) マンキチ地区， $2 \mathrm{~km}^{2}$ ) に区分して順 次調查を進めた（Fig. 1)。調査地区(1)，(2)，(3)は 大幅に重複している。

定点調查と同時に熟練した研究者が調查地域内 の群れを直接追跡した。追跡者は，たえず群れの 広がりの中に位置し，群れの位置を30分毎に記録 した。

群れの発見効率を，群れ之一定の距離関係にあ る定点の何割が定時にその位置を把握していたか で定義し，てれと探索距離との関係をまず検討し た。また，各調査日に扔いて正時でとの積算発見 集団数の变化を整理し，どの時間帯に集団が発見 され易いかを検討した。さらに，複数の群れの分 布が長期観察によりわかっている半山地区で二回 調查を繰り返し，てのセンサス法の精度 (既知の 群机数の何パーセントを把握できたか）と再現性 を検討した。群れ数が末知の川原地区と, 半山一 カンカケ(B)地区においてす 2 回調査を繰り返した。 また, 半山一カンカケ(A)地区下部の $2 \mathrm{~km}^{2}$ では, 半山地区と共通するので, 同じ調査を 3 回繰り返 したことになり, 同じく再現性を検討した。

\section{結 果}

\section{群れ追跡との比較}

直接追跡は，8月 3 日8:30-14:40，7日09 :40-12:30, 14:15-15:00,8日07:3515:14の計17時間 6分行った。この3 日間は晴れ か量りで風は無しか微かだったので，天候の発見 効率への影響は考えなかった。

直接追跡時に30分毎に群れの位置を39点記録で きた。39点の群れの位置の内， $51 \%$ は 1 点ないし 2 点の定点から確認された。群れの発見の手がか りは, 記録不備の 2 例を除く之, $92 \%$ (22例) が 音によるものであり，2例だけが姿の確認によっ た。発見の手がかりとなった音の内，10例は叫び 声 (Itani, 1965のA-7〜A-12) や悲鳴 (Itani, 1965 のB-1〜B-3) などのサルの大声，1例は 枝摇れの音とともに聞こえたクークーという鳴き 交わし（Itani，1965のA-2）だった。残り11例 
は，サルの音声であるが，その種類については記 録不備のため不明だった。

定点と群れとの水平距離と発見効率との関係を 検討した。直接追跡されている群れの位置との距 離が $1.1 \mathrm{~km}$ 以内になった199例について分析し た。他の調査員から連絡を受けた場合も含めて調 査員が群れの存在を確認できた最大の距離は 722 $\mathrm{m}$ ，他からの情報なしで自分で群れを発見できた 最大の距離は $712 \mathrm{~m}$ であった。

発見効率 $\mathrm{g}(\mathrm{y})$ は調査員と群れとの距離 $\mathrm{y} か ゙$ 長く なればなるほど指数関数的に減少した (Fig. 2)。 そこで Gates et al. (1968) の仮説に従って発見 効率を指数関数で近似すると次式で表わされた。

$$
\mathrm{g}(\mathrm{y})=\operatorname{EXP}(-0.0036 \mathrm{y})
$$

定点がブロックの中央にあるとすると, 定点か
らブロックの境界までの距離は $250 \mathrm{~m}$ から約 $350 \mathrm{~m}$ となり，境界での発見効率は $0.41 〜 0.28$ となる。

\section{時刻と発見群れ数}

一日で発見される総集団数の75\%は，午前10時 までに発見された（Fig. 3)。それ以降は14時から 15時に発見群れ数の増加がややみられ，以降は発 見群れ数の増加はない。

\section{精度と再現性}

実数10から11の群が存在すると考えられる半山 地区 $\left(3 \mathrm{~km}^{2}\right)$ で調査を 2 回行った。1 回目は調 査初日で, 定点観察により 2 群(実数の18-20\%), 2 回目は 1 回目調査の翌日で 7 群が確認された(実 数の64-70\%)。また川原地区，半山ーカンカケ地

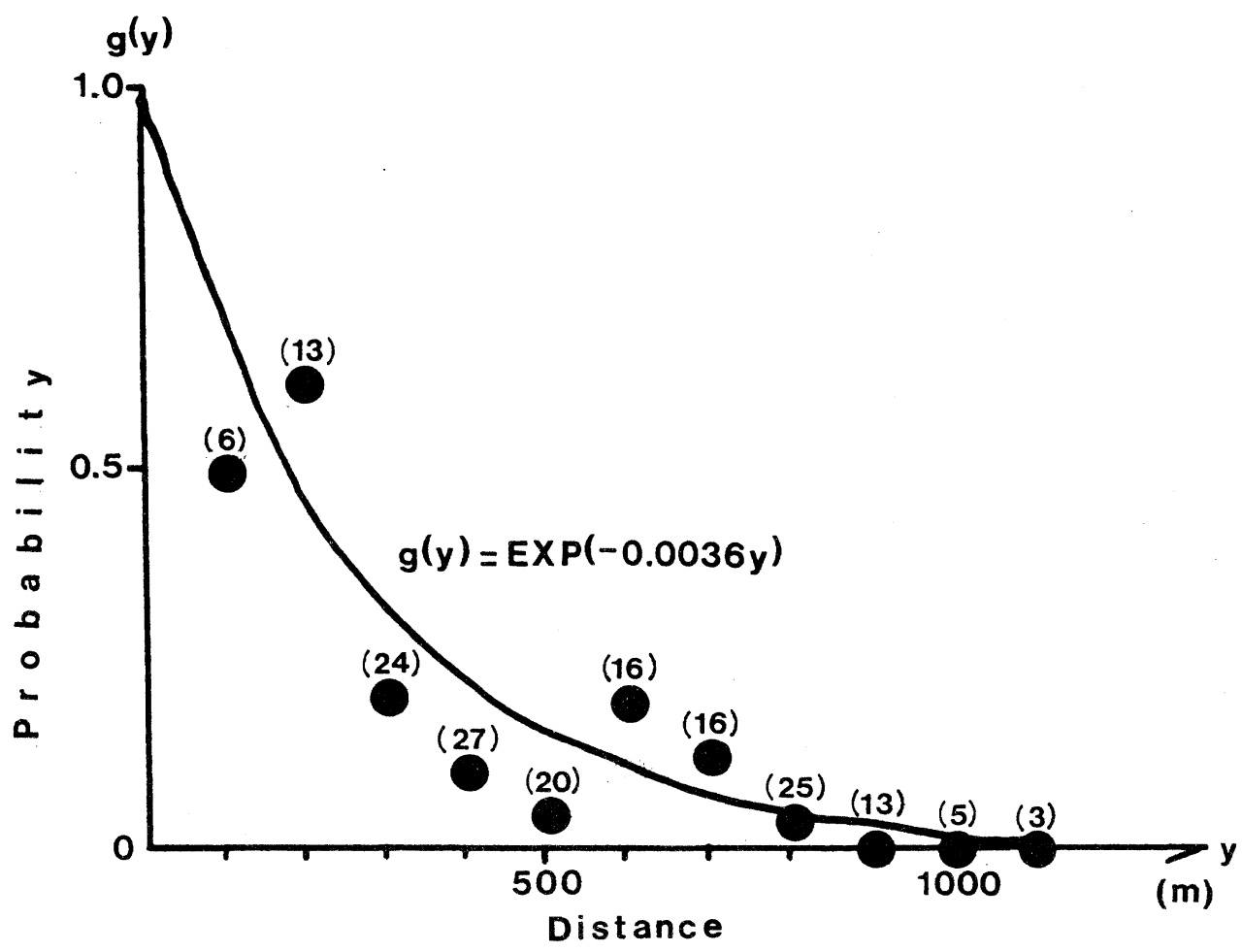

Fig. 2. Detection curve against distance from the group.

The vertical axis is detection efficiency (probability), and the horizontal axis is the distance between the observer and the monkey group. The numbers in parentheses are sample sizes. 


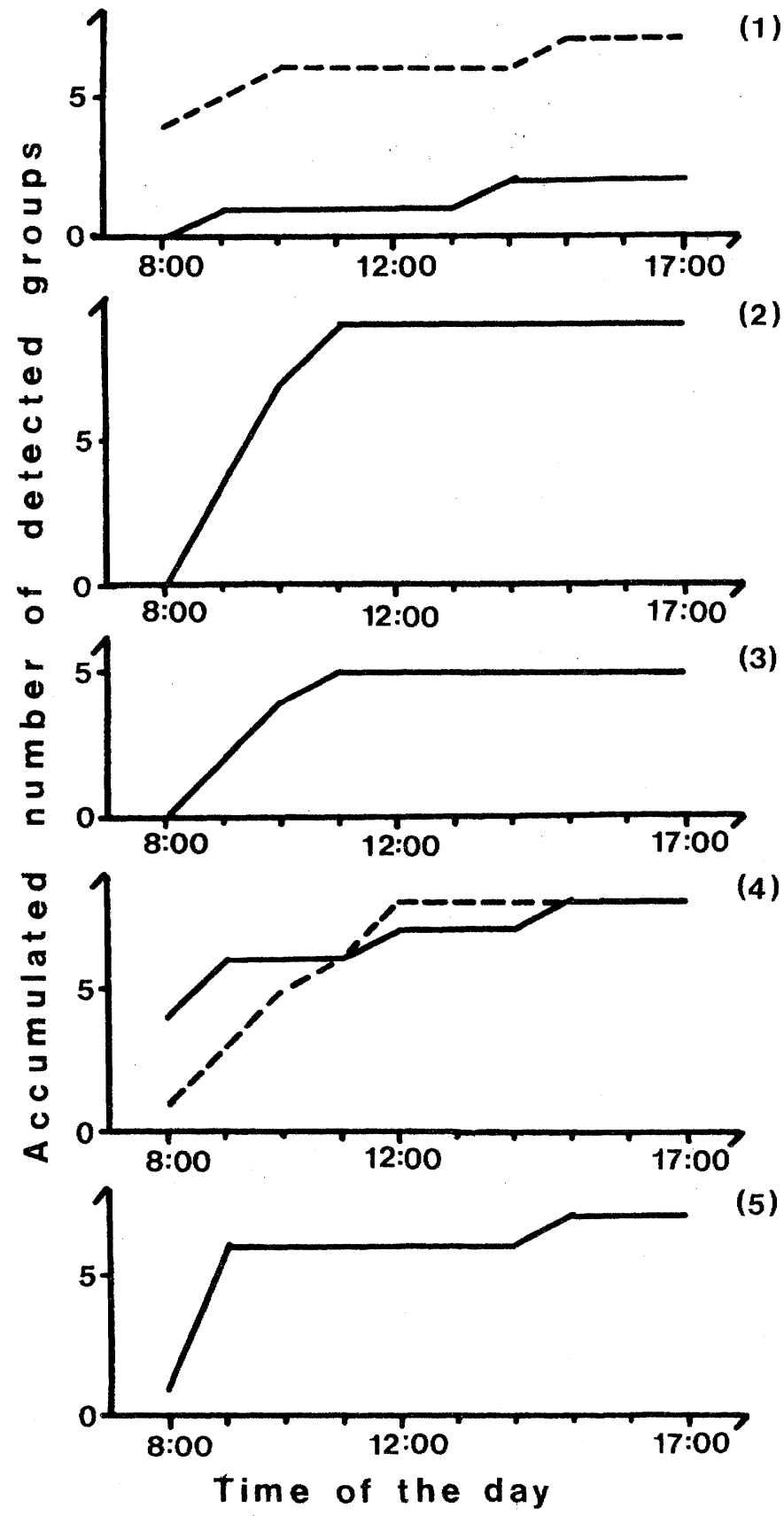

Fig. 3. Accumulated number of detected groups at each time of the day. (1) Hanyama area, (2) Hanyama-Kankake (A) area, (3) Hanyama-Kankake (B) area, (4) Kawahara area, (5) Mankichi area. Broken lines represent the results of the second trials. 
区(B)で各々 2 日間行った調査では両日とも発見 群れ総数は同数（各々 8 群，5群）となった。半 山一カンカケ地区と半山地区の共通の $2 \mathrm{~km}^{2}$ の部 分 (実数 9 群) では, 1 回目は 2 群 (実数の $22 \%$ ),

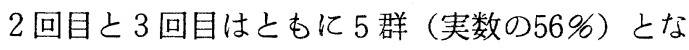
った。

\section{議論}

ニホンザル社会の単位集団である群れは，時に 離合集散を行うことが知られている（Fukuda, 1989)。ブロック分割定点調查法では，主に音声を たよりに遠方から観察が行われるので，集団どう しの社会交渉は詳しく観察できず，集団の合流， 分離の社会的意味合いを決定できないことが多い し，観察時間を超える集団の分離は探知できない。 よって，乙のセンサス法では群れから一時的に分 離することにより発生した個体の集合あ数え上げ, 群れ数を過大に評価する危険性が考えられた。し かし, 実際の群れ数推定の結果は過小評価となっ た。これは，(1)集団の発見効率が通常 1 よりかな り小さいこと, (2)調查地域の二ホンザルは，せい ぜい $1 \mathrm{~km}^{2}$ 程度の遊動域しか持たず（丸橋他, 1986)，群れが広がり，離合集散が起きるのはその 狭い中においてであるので，離合集散が起きても 群れの広がりとして捉えられる傾向があることに よると考えられる。逆に，離合集散する群れの遊 動域が広く，分離集団同士がかなりの距離離れる 地域では，分離集団どうしが一つの群れであると いう判断の根拠を得ることは難しく，個々の分離 集団をそれぞれ一つの群れと数えてしまうことが 多いだろう。このように，群れ数推定を目的とし てての方法を選択する場合には, 調査地域の群れ の遊動域の大きさや離合集散などサルの行動特性 屯考慮して, 得られた結果の偏りについて検討す る必要がある。

一方，生息個体数の推定は，発見された集団が 群れであろうがなかろうがその集団数と平均集団 サイズとの乗算で行える。乙の場合には，集団の 探查と併せて，林道など見通しのよい場所をサル が渡る機会などを利用して複数の集団サイズのカ ウントを行い平均の集団サイズを推定する。
半山地区では, 調査初日にあたる 1 回目より調 査 2 日目にあたる 2 回目の調査の精度が著しく高 かった。調查者のほとんどが, 調查未経験者であ り，2 回目で探索能力が向上したあのと考えられ る。また，調査に充分慣れたと考えられる 2 日目 以降 3 地区での繰り返し調査では, 集団の発見数 は同一だった。調査者が未経験者でも，1日ない し2 日間の訓練のための調査を行えば再現性のあ る調査を行えるといえる。

また，調査の開始後 3 時間で，その日発見した 集団数の $75 \% ， 8$ 時間で $100 \%$ を発見した。乙れ は, 二ホンザルの活動の日周変化に伴い発見の手 がかりとなる行動の頻度が変化することと, 調查 者の疲労の蓄積が関係していると考えられる。と あかく朝 7 時から調查を始めた場合 8 時間程度の 調查時間で充分な精度の調査が行えることが経験 的に明らかになった。より効率よく調査を行うた めには，サルが叫び声を比較的頻繁にあげる時間 帯の検討を行い，それに併せて調査時間を設定す る必要があるだろう。

発見効率は，距離が増加する之指数関数的に減 少した。発見は主にサルの音声によっており, 二 ホンザルの音声伝播の物理モデルや人間の可聴域 から $\mathrm{g}(\mathrm{y})$ の型を推定し，今回得られた経験式の妥 当性を検討する必要がある。群れの発見効率は, 調查精度と関係するが，乙れに影響を与える要因 として, 探索距離や調查者の可聴能力の他に, 調 査者の熟練度, 天候, 風, 調查地の植生, 調查の 時間帯, 調査地の地形などが挙げられる(Burnham, Anderson, \& Laake, 1980)。また, 猿害地で駆除 圧を受けている群れや小サイズの群れでは音声の 発生頻度が少なく発見効率が低くなるという指摘 がある（鹿児島大学鳥獣害研究会，1993）。理想 的にはそれぞれの要因之発見効率の関係を定式化 しておく必要があるが，実際上は不可能であり， より簡便には，定点調査と同時に群れ直接追跡を 行い, 追跡されている群れの発見効率を今回の結 果と比較することにより, 調査全体の精度につい ての打扔まかな目安を得るといい。直接の群れ追 跡が困難なところでは，あらかじめ群れ個体に電 波発信機の装着を行って電波追跡を併用するてと 
あ考えられる。

我々が経験的に決定したブロックの大きさでは, 平方キロメートル当たり 4 人の未経験者を調查員 として投入することにより，60-70\%の精度の調 查が可能だった。発見効率は距離と逆相関するの で, ブロックが小さいほど精度の高い調査ができ るが, 一定の面積の調查地域に対し調査員の動員 数が大きくなる。目的, 予算, 安全性, 調査期間 などあ勘案してブロックの大きさは適宜決定すれ ばよいだろう。ただし，精度の低下はてれ以上望 ましくないのでブロックを大きくすることは避け た方がよい。全調查域の形状は，単独のブロック からしか探査できない地域が少なくなるよう，で こぼこのない方形が望ましく，理想的には 4 つの 定点から探査が行われる地域の数が増えるよう正 方形になるよう設定するのが望ましい。

\section{謝 辞}

ての調査を行うにあたって次の方々に, 調査員 として協力をしていただきました。青木保，東隆 蔵, 阿部美穂, 池田博司, 石川学, 伊藤豊, 岩槻 好太郎，上辻宏，片山忍，木戸口剛士，倉品治男， 高津文人，神山義徳，近藤あや子，白戸圭一，四 戸宮治朗, 関根雅夫, 田崎純, 田中香, 田中希, 中島健介, 中田健二, 中山裕理, 花沢明俊, 古市 剛史，堀切竜也，脇田しをり，増山典久，丸橋珠 樹, 三浦耕太, 村木優子, 山極寿一, 芳田和雄, NDODA MUWANZA（アイウエォ順，敬称略）。 京都大学霊長類研究所渡辺邦夫氏には草稿を読ん でいただき，有益なコメントをいただきました。 調査費の一部として, 京都大学霊長類研究所共同 利用研究費 (好廣, 手塚), 霊長類学会保護基金 の提供を受けました。感謝いたします。

\section{参考文献}

東 滋, 大竹 勝, 山極寿一, 他 1984 : 屋久島原 生自然環境保全地域のヤクザルの生態. 屋久島原生 自然環境保全地域調査報告書, 環境庁自然保護局, 東京, pp. 517-568.

Brockelman WY, Ali R 1987: Methods of surveying and sampling forest primate populations. In Marsh CR \& Mittermeier RA (eds): Primate Conservation in the Tropical Rain Forest, Alan R. Liss, New York. pp.
$23-62$.

Burnham FP, Anderson DR, Laake JL 1980: Estimation of density from line transect sampling of biological populations. Wildlife Monographs, 72: 7-202.

Defler TR, Pintor D 1985: Censusing primates by transect in a forest of known primate density. Int. J. of Primat. 6: 243-259.

Fukuda F 1989: Habitual fission-fusion and social organization of the Hakone Troop $\mathrm{T}$ of Japanese macaques in Kanagawa Prefecture, Japan. Int. J. of Primat. 10: 419-439.

Gates CE, Marshall WH, Olson DP 1968: Line transect method of estimating grouse population densities. Biometrics, 24: 135-145.

Itani J 1963: Vocal communication of the wild Japanese monkey. Primates, 4: 11-66.

鹿児島大学農学部鳥獣害研究会 1993 : ヤクザル生息 奏態調查報告. 鹿児島県, 鹿児島。

Maruhashi T 1980: Feeding Behavior and diet of the Japanese monkey (Macaca fuscata yakui) on Yakushima Island. Primates, 21: $141-160$.

丸橋珠樹, 山極寿一, 古市剛史 1986 : 屋久島の野生 二ホンザル. 東海大学出版会, 東京.

田川日出夫 1980 : 屋久島国割岳西斜面の植生. 鹿児 島大学理科報告, $29: 121-137$. 


\title{
(Summary)
}

\section{Reliability of a New Method to Census Japanese Macaques: Fixed Observers in Quadrats}

\author{
Toru $\mathrm{OI}^{1)}$, Shinichi YOSHIHIRO ${ }^{2)}$, Hideo HIGASHI ${ }^{3)}$, \\ Makito TEZUKA ${ }^{4)}$, Shigeru AZUMA ${ }^{5)}$ \\ 1) Tohoku Research Center, Forestry \& Forest Products Research Instituite \\ 2) Department of Economics, Ryukoku University \\ 3) Wildlife Workshop \\ 4) Wildlife Management Office \\ 5) Primate Research Institute, Kyoto University
}

We devised a census method that uses fixed observers in quadrats to estimate the density of Japanese macaque groups or populations. A research area is divided into $500 \times 500 \mathrm{~m}$ quadrats. Observers are positioned in each quadrat at a fixed point where they can get a good view over the quadrat. The observers simultaneously search monkey groups both visually and auditorially, and map the movement of the groups. To avoid duplication in counting, the observers communicate with each other by radios. At the end of the census, the number of groups detected was summed. This method can also be used to estimate population density if the number of individuals in groups is counted. Unexperienced students conducted this census in $9.5 \mathrm{~km}^{2}$ steep mountain area of Yakushima Island where a line census was impracticable. Individual censuses were conducted over areas of 2 to $4 \mathrm{~km}^{2}$ from 7:00 to $17: 00$. This area included the $3 \mathrm{~km}^{2}$ area where 10 or 11 groups were known to inhabit from studies since 1973. This area was used to measure the accuracy of the method. Three different areas were censused two or three times to evaluate the precision of the method. Furthermore, experienced observers moved with monkey groups to record the exact positions of the groups in order to measure the detection efficiency of fixed observes. Monkeys were mostly detected by loud calls, and $75 \%$ of groups were found within 3 hours after start of observation at 7:00 A.M, and after 8 hours no new groups were detected. Detection efficiency was measured as the ratio of the number of observers who found the position of groups to the number of all observers tested. The detection efficiency exponentially decreased as the distance between the observer and the group increased. The maximum observer-to-group distance was $720 \mathrm{~m}$. In the first day of the observation in an area where the number of groups had been known, unexperienced students detected about $20 \%$ of the groups, but in the second day they detected $60-70 \%$ in the same area as the first day. Repetition of censuses in the other areas resulted in the same counts of the groups in different censuses in each area. We conclude that this method can be successfully used in steep mountainous areas even by unexperienced field assistants, with sufficient accuracy and precision if a prior survey excercise of one or two days is conducted. If this method is applied in an area with different conditions, evaluation of accuracy is first needed. 